\title{
第75 回日本医科器械学会大会の開催にあたって
}

第75回日本医科器械学会大会 大会長馬杉 則彦 (横浜労災病院 副院長)

あけましておめでとらございます。コンピュ ータ2000年問題もクリアーして清々して新年を 迎えられたことと打慶び申し上げます。

第75回日本医科器械学会大会は, 本年 6 月 1 日（木），2日（金），3日（土）の3 日間, 横 浜みなとみらいの “パシフィコ横浜”で開催さ れます。

既につぎの先生方に企画委員を委嘱して良い 大会にするべくいろいろなアイデアを出して頂 きました。また引き続きプログラム委員会のメ ンバーにもなって頂きました。

企画委員（敬称略）：新井晴代，井村睦昭， 落合慈之, 大久保 憲, 釘宮豊城, 根本 達, 松本謙一, 三宅寿美, 永井 勲, 村中重明, 山田芳嗣

テーマは “節目の年一 2000 年一の医科器械 学”といたしました。“2000 年”さらに“第 75 回”とまことに区切りの良い節目に当たる大会 です，過ぎ去っていく20世紀を省みて統括し， これを礎にして新しい世紀をしっかりとした足 取りで進んでいくよらな大会にしたいと考えて 扣ります。

会場となりますパシフィコ横浜は，1998年に 小林大会長のもとで第73回大会が催されました ので皆様良くご存じのことと思います．前回か ら 2 年の間にみなとみらいはさらに大きく発展

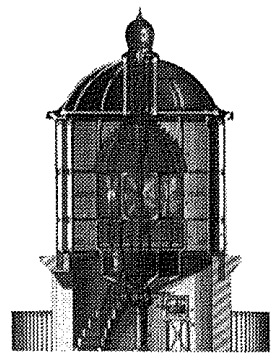

第75回大会シンボルマーク

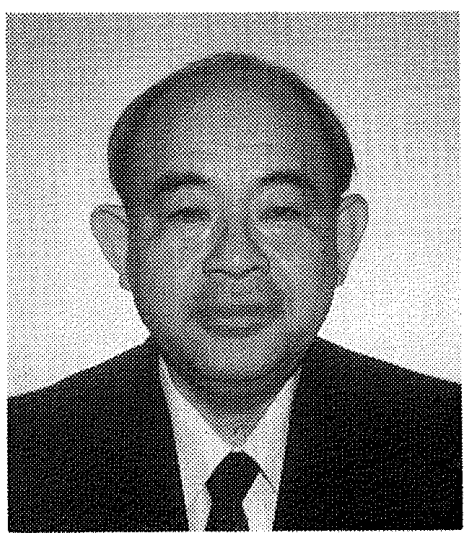

しましたそその変貌振りに驚かれることでしょ う。大会の合間に散策して頂きたいと思いま す.このような状況から大会のシンボルマーク は“燈台”にしました，横浜の港を象徵し，こ の灯が21世紀に向けての足取りの目標となるこ とを祈念したものです。

通常の本大会では“大会長講演”があります。 しかし私自身は今までに大した業績があるわけ でなく，ただただ周囲の皆様の応援で今日があ るわけです。そこで今回の大会ではその主旨を 活かして，新しく“大会長シンポジウム”とい うものを企画しました。この新年号に揭載され て扣ります座談会は昨年10月末に行ったもので すが，私が司会をしまして，これほど楽しくか つ有意義な座談会を経験したことは未だかつて ありませんでした，その際に，これこそ本大会 で取り上げる題材と感じました。そのようなわ けで，今回の大会では “20世紀の総括一21世紀 への課題一”といら題のもとに, 座談会と同じ メンバーで “大会長シンポジゥム”として開催 させていただきます。

特別講演は札幌医科大学脳神経外科端和夫教 授に “脳神経外科手術と医科器械” に関して, 日頃の總蓄を傾けていただくことにしました。 


\section{( 2 ) 医器学 Vol. 70, No.1 (2000)}

昨年の医科器械学11月号に私が “医科器械から 見た低侵襲手術の現状”といら特集を組及まし た．その巻頭で触れましたが，日本医科器械学 会には従来手術用機器研究会というものがあり, 三浦哲夫先生怙よび引き継がれました都築正和 先生らのご尽力で, 長年にわたり精力的に仕事 をしてきました。これらを振り返って見ますと， 再三にわたり脳神経外科領域の題材が出てまい ります，要するに脳神経外科と医科器械とは切 っても切れない繫がりがあると思われます，端 教授はこの点に早くから注目され，脳神経外科 の先生方の中にこの分野の学会を設立された方 です，先生の豊富な経験の中からどんな講演が 聴けるか期待して招ります。

また，(財) 日本医科器械資料保存協会の平成 11年度 “医科器械史研究賞”を受賞されました 原学園臨床研究所 白井 洸 所長に “人工腎臓 （血液透析）の歴史と研究”について扣話して
いただくことにしました.

いろいろな職種の方にご参加頂きたいのです が，今回は特にナースの方々に多数ご出席頂き たく，企画委員にも 2 人のナースに入って頂き ました，とかく医師や臨床工学技士の視点が多 くなるところを，ナースの視点で捉えることを 目指しております。

このほか現時点ではハッキリとしたことは言 えませんが，コンピュータ2000年問題に関して のシンポジゥムも予定して扣ります。内容につ いては新年を迎えて，この問題についてのある 程度の決着がついた時点で考学る予定です．1 題でも多い演題と，1 人でも多い参加者を心か ら持待ら申し上げます。

最後に，併設します “総合医科器械展” 女節 目の年に相応しい素晴らしいものになりますよ らに期待しております。 